\title{
ДИПЛОМАТИЯ
}

Косенко С.И.

DOI: 10.7256/2305-560X.2015.2.10167

\section{ФАКТОР «МЯГКОЙ СИЛЫ» В КУЛЬТУРНОЙ ДИПЛОМАТИИ ФРАНЦИИ}

\begin{abstract}
Аннотация: В настоящей статье рассматриваются некоторые актуальные аспекты культурной дипломатии Франции как атрибута "мягкой силы»; подчеркивается традиционно особое место культурной политики в стратегии сохранения и усиления глобального влияния Франции в условиях скрытого противостояния лингвокультурному давлению США и их претензиям на духовное лидерство в современном мире. Мягкая сила всегда играла большую роль в реализации Францией своей внешней политики. По мере расширения глобализации все более острой и злободневной для стран с развитой культурой становится задача сохранения и защиты своей национальной самобытности и цивилизационного своеобразия. В этом смысле великая культурная держава - Франция - являет собой яркий и убедительный пример страны, которая, благодаря целенаправленной и продуманной государственной политике в области культуры, на протяжении веков твердо отстаивала и продолжает успешно отстаивать свою «культурную исключительность».
\end{abstract}

Ключевые слова: международные отношения, внешняя политика, Франция, мягкая сила, дипломатия, сотрудничество, государство, интересы, ченности, безопасность.

$\mathrm{P}$ ассмотрение культурной политики Франции в контексте проблематики «мягкой силы» или soft power ${ }^{1}$, по мнению автора, прямо соотносится с насущными задачами внутренней и внешней политики современной России. Во-первых, традиционная культура и моральные ценности нашей страны в условиях глобализации также испытывают на себе негативные последствия заокеанского прессинга, что, в свою очередь, требует адекватного противодействия. Во-вторых, в отличие от Франции, культура как фактор «мягкой силы», как средство повышения привлекательности имиджа страны и, соответственно, усиления ее авторитета и влияния в окружающем мире занимает пока еще мало места во внешнеполитической доктрине и в практических действиях России на мировой арене.

9 июля 2012 г. на Совещании послов и постоянных представителей России президент России Владимир Путин, пожалуй, впервые обратил внимание отечественной дипломатии на необходимость использовать в работе «мягкую силу». Это подразумевает «продвижение своих интересов и подходов путем убеждения и при-

1 В российской научной литературе встречаются разные варианты перевода этого термина - «мягкая власть», «мягкая сила», «мягкое могущество». Поэтому, в зависимости от контекста, автор сознательно использует различные версии перевода soft power. влечения симпатий к своей стране, основываясь на ее достижениях не только в материальной, но и в духовной культуре и интеллектуальной сфере»². В это связи один из исследователей этой проблематики профессор МГИМО Елена Пономарева справедливо обращает внимание на то, что «роль и значение «мягкой силы» (MC), которая использовалась еще в подготовке крушения советской системы и вплоть до реализации проекта «твиттер-революций» в арабском мире, постоянно возрастает. Сегодня практически ни одно даже малозначимое событие в мировой политике не происходит без использования МС, многократно усиленной новейшими информационными и когнитивными технологиями. Более того, в современных условиях именно «мягкая сила» зачастую обеспечивает информационную артподготовку, готовит плацдарм для прямого военного вмешательства. Поэтому пришло время исправлять допущенные ошибки - «мягкая сила» становится одной из опор российской внешней политики» ${ }^{3}$.

\footnotetext{
2 Выступление Президента РФ на Совещании послов и постоянных представителей России. 9 июля 2012. URL: http:// президент.рф/news/15902.

3 Пономарева Е.Г. Железная хватка «мягкой силы» // Однако. 2013. № 6. URL: http://www.odnako.org/magazine/material/ show_24128.
} 


\section{Международные отношения / International Relations / № 2 / 2015}

\section{«Мягкая сила» как фактор влияния}

Уже давно ни для кого не секрет, что именно сильная Россия, а отнюдь не идеологически враждебный Западу Советский Союз, всегда была и остается главным геополитическим и стратегическим противником США в их стремлении к мировому господству, в поисках новых, легкодоступных природных ресурсов. Поэтому и сегодня против уже «неокапиталистической» России США и их союзники, как и в советские времена, активно используют для ослабления «московского режима» и «разрыхления» всех тканей российского общества испытанные средства «мягкой силы». В частности, наряду с продуктами массовой культуры и шоу-бизнеса в процессе формирования особого культурного и психологического климата, как в России, так и вокруг нее наши западные визави используют окрики, нравоучения, назидания и развесистую демагогию на темы прав человека, абсолютной свободы личности, творчества, информации, выражения идей, мнений и т.п.

В этом идейном противоборстве, которое вполне можно квалифицировать как рецидив Холодной войны со стороны США, противники крепкой России добились определенного успеха - за двадцать с небольшим лет «демократического» развития, ее, как и большинство стран планеты, буквально захлестнула волна низкопробной продукции массовой заокеанской культуры. Но, что более печально и тревожно - в общественном сознании россиян все больше утверждаются признаки и стереотипы американского мышления/ менталитета со ставкой на сакрализацию и культ богатства и силы, на пропаганду наживы, аморальности и вседозволенности, т.е. качеств, прямо противположных исконной русской нравственности, морали и высокой русскоязычной культуре, объединяемых понятием «духовность». Такая «идейная обработка мозгов» особенно опасна в условиях практически бесконтрольного доступа населения к новейшим техническим средствам информатиции и коммуникации (мобильная телефония, интернет, социальные сети и т.п.), производство и сбыт которых, как известно, контролируются транснациональными или чисто американскими компаниями в планетарном масштабе.

В таких условиях «культурной» интервенции, основная задача новой политики России в области культуры и - шире - в гуманитарной сфере видится, прежде всего, в решительном противодействии лингвокультурному давлению из-за океана, на- целенному на дебилизацию населения страны, на его духовное перерождение, порабощение и окончательное превращение в бездумного потребителя суррогатной «культурной» заокеанской продукции. Для краткости эту задачу можно обозначить как возрождение российской духовности. В этом вопросе французский опыт может оказаться весьма и весьма полезным. Франция, будучи на протяжении почти двух веков признанным духовным «маяком» западной цивилизации, по мере наступления американского гегемонизма - после создания Версальской системы в 1918 г. и особенно после Второй мировой войны - постепенно стала утрачивать эту роль. Однако за счет проведения последовательной и эффективной государственной культурной политики, как одного из атрибутов своего «мягкого могуществ» («puissance douce»), смогла в известной степени сохранить национальное своеобразие, престиж и влияние в международных делах. Несмотря на все имеющиеся факты «упадка» влияния Франции в последние годы, следует признать, что оно не измеряется только военными, экономическими и политическими факторами. Это влияние в полной мере определено ее способностью привлекать своим образом жизни, своими идеями и знаниями, культурой, иными несиловыми и нематериальными факторами. Именно «мягкое могущество» позволяет Франции и сегодня в условиях жесткой конкуренции сохранять в международных отношениях свои приоритеты и отстаивать свои позиции. Такое положение вещей обусловлено, в частности, тем, что внешняя культурная и научная политика всегда находились и находятся в центре внешнеполитической стратегии этой страны, обеспечивая сохранение и даже расширение французского влияния.

Видный французский историк Фернан Бродель в своей фундаментальной работе «Грамматика цивилизаций» утверждал, что любая традиционная культура всегда привязана исторически и географически к определенному обществу и не может существовать, совершенствоваться и передаваться вне общества 4 . По Броделю, в мире нет обществ, не обладающих своей собственной, специфической культурой - национальной, народной (на уровне страны), региональной (эльзасской, баварской или каталонской), буржуазной или пролетарской (в зависимости от социальной ориентации), элитарной или массовой и т.д. Но в любом случае, будучи тес-

4 Braudel F. Grammaire des civilisations. Paris: Arthaud, 1987. P. 13-14. 
но связанной с языком, такая самобытная культура является показателем и сущностью неповторимой индивидуальности данного народа или социальной группы.

Глобализация же стремится размыть или разрушить эти рамки, рассматривая культуру и культурную «продукцию» сугубо под коммерческим углом, с точки зрения получения торговых преимуществ и прибыли. Поэтому именно Франции мир обязан тем, что в итоге переговоров, ведущихся уже много лет в рамках Всемирной торговой организации (ВТ0), культурная продукция до сих пор не признана «обычным товаром». Движение именно французских антиглобалистов привело в апреле 1998 г. к провалу пресловутого Многостороннего соглашения об инвестициях (AMI), куда англосаксонские противники Франции во главе с США хотели записать это определение, а в ноябре того же года - к отмене встречи ВТО на высшем уровне в Сиэттле.

Для понимания пагубного воздействия глобализации на культуру необходимо провести четкое разделение между понятиями «культура», как производное духа, и «культурной индустрии», как феномена и результата экономического развития. В этой связи необходимо вспомнить представителей т.н. франкфуртской школы, видных западных социологов Теодора Адорно и Макса Хоркхаймер, которые впервые использовали термин «культурная индустрия» еще в 1947 г. в своей известной работе «Диалектика просвещения» 5 . В этой работе они единодушно осудили индустриальное воспроизведение продуктов культуры, усматривая в нем угрозу не только художественному творчеству, но и опасность подавления личности, индивидуальности. Немецкие ученые не без оснований утверждали, что такая «стандартизованная и приукрашенная культурная продукция служит орудием манипулирования послушными и пассивными массами» ${ }^{6}$. Следует добавить, что все приверженцы франкфуртской школы (в т.ч. Герберт Маркузе) выделяли негативную сторону искусственной стандартизации и «маршандизации», т.е. «отоваривания» культуры. Не случайно на мировом рынке культурной продукции ведется ожесточенная конкурентная борьба, в которой побеждает тот, кто обладает не более богатой культурой,

\footnotetext{
5 Adorno T., Horkheimer M. Dialectic of Enlightenment. Stanford: Stanford UP, 2002. 304 p.

6 Adorno T., Horkheimer M. Dialectic of Enlightenment..., P. 94-95.
}

а материальным и техническим превосходством в сфере культурной индустрии. Поэтому в условиях глобализации на скорую гибель и исчезновение обречена не только традиционная культура «примитивных» народов, но и специфика стран с развитой высокой культурой, не обладающих достаточной экономической и технической мощью для соперничества с культурной индустрией, прежде всего, США - страны, которая навязывает миру некую глобальную модель культуры. Именно по этой причине Франция, которая всегда противилась «рыночному» подходу США к культуре, еще в 1993 г. на переговорах в рамкх ГАТТ заявила о своем праве на «культурную исключительность» и, в конечном счете, настояла на исключении аудиовизуальной сферы из переговоров о «свободной торговле» по линии ВТО.

За последние два-три десятилетия, по мере исчезновения биполярной системы и становления «нового мирового порядка», западная, и в т.ч. французская политическая наука стала уделять растущее внимание проблематике «мягкого могущества» (французам больше импонирует этот термин (puissance douce, нежели «сила/force» или «власть/ pouvoir»), как эффективному средству продвижения государством своих национальных интересов и распространения в новых условиях своего влияния несиловыми методами, т.е. без принуждения Эта тема с недавнего времени все больше интересует и российских ученых ${ }^{8}$, хотя целый ряд аспектов этой проблематики в нашей науке остается пока еще неохваченным и неизученным.

\section{Борьба за «мягкое могущество»}

В условиях глобализации, а, вернее, американизации современного мира, именно Франция, умело используя инструменты «мягкого могущества», продолжала и продолжает сохранять свою неповторимую национальную идентичность и отстаивать свои национальные интересы, в т.ч. в области

\footnotetext{
См., в частности, Montbrial de Th. Vingt ans qui boulversèrent le monde. Paris: Dunod, 2008;. Vaïsse M. La puissance ou l'influence? La France dans le monde depuis 1958. Paris: Fayard, 2009 и др.

8 Например, Алексеева Т.А. Россия в пространстве глобального восприятия // Международные процессы. 2007. Том 5. №2 (14); Обичкина Е.О. Франция в поисках внешнеполитических ориентиров в постбиполярном мире. М.: МГИМОУниверситет, 2003; Пономарева Е.Г. Железная хватка «мягкой силы» // Однако. 2013. №№ 6,7; Филимонов Г.Ю. «Мягкая сила» культурной дипломатии США. М.: РУДН, 2010.
} 
культуры, когда остальные, видные в прошлом культурные державы (как, например, Италия или Германия), покорно «легли» под американский нивелирующий культуру «каток». Вот почему опыт и пример культурной политики Франции, особенно за последние десятилетия представляет очевидный научный, практический и общечеловеческий интерес. Особое значение для российского исследователя имеет также как латентный, так и открытый антиамериканизм государственной культурной политики Франции.

Так, одним из конвергентных пунктов мышления российских и французских политологов в этой связи, является мнение о том, что естественная глобализация, порождаемая объективным и необратимым свободным движением человеческих и культурных потоков, капиталов и ресурсов, вовсе не тождественна навязываемой из-за океана «идеологии глобализации» - наследницы идеологической борьбы периода биполярного мира, но оставшейся жупелом либерального сверхобщества под американским «глобальным управлением». Напомним, что концепция, с которой Америка вступила на мировую арену накануне Первой мировой войны, была охарактеризована как «вселенская, основополагающая гармония, пока что скрытая от человечества» ${ }^{9}$. Уже на Парижской мирной конференции 1919 г. президент Вильсон провозгласил, что, «Америке уготована невиданная честь осуществить свое предназначение и спасти мир ${ }^{10}$.

До этого носителем такого вселенского мессианства позиционировала себя и была признана Франция, Однако именно с данного исторического момента США стали неуклонно оттеснять ее с этого пъедестала. По признанию исследователей американского мессианизма и его религиознофилософских истоков именно вильсонианство соединило с либеральным посылом кальвинисткую доктрину «богоизбранности» англосаксонских пуритан, которая провозглашает моральное право на экспансию и руководство «дикарями и народами зла». А показателем богоизбранности, согласно этой доктрине, является земной успех и богатство. Выходит, что в наши дни девиз на государственной печати США «Novus Ordo Seclorum» - «новый порядок навсегда», воплотился в спайке империализма времен Теодора Рузвельта и мессианизма в духе Вудро Вильсона.

9 Нарочницкая Н.А. Россия и русские в современном мире. M.: ЭКСМО, 2011. С. 263.

10 Там же.
В этой связи напомним, что для Франции идеальное представление о своем мировом ранге традиционно было едва ли не важнее объективных факторов. Тем самым, изначально расширялись рамки возможного для волюнтаристской политики раннего голлизма, что, в свою очередь, соответствовало обоснованию международных амбиций Франции при недостатке материальных средств перед США. Примечательно также, что один из основных идеологов «французской школы», заядлый атлантист и «антисоветчик» Раймон Арон, в книге «Мир и война между нациями» в принципе отрицал монополию какого-либо государства в мире. Ему же принадлежит классическое определение «могущества», принятое сегодня во французской политологии, - как «способность одной политической единицы навязать свою волю другим и не дать другим навязать ей свою волю» ${ }^{11}$.

Поэтому с рождением голлистской республики в 1958 г. восстановление былого внешнеполитического могущества Франции и утверждение ее независимости в международных делах стало центральной темой работ по теории международных отношений в этой стране и основой французской дипломатии. Соответствующую направленность с того момента получила и внешняя культурная политика Франции. Причем, в отличие от ядерных сил, призванных «устрашать и сдерживать» потенциального противника/агрессора, культурная политика Франции всегда была направлена главным образом на обеспечение «блистания/сияния» (rayonnement) Франции в мире, т.е. на восхищение ею, ее идеями и ее действиями. Быть признанной на мировой арене в качестве глашатая и носителя «универсальных» гуманистических ценностей такова суть традиционных мессианских устремлений Франции во внешней политике. Эта цель лежит за пределами простого обеспечения безопасности, ибо призвана содействовать усилению планетарного влияния страны и направлена на утверждение ее величия методами «мягкого могущества». Именно из этой идеи исходила Франция со времен Людовика XIV, определяя свое место в мире.

Как известно, понятие «soft power» было введено в научный оборот профессором Гарвардского университета Джозефом Наем в начале 1990-х годов $^{12}$. В начале XXI в. Най дополнил и развил концеп-

11 Aron, R. Paix et guerre entre les nations. Paris: CalmannLévy, 1984. P. 58.

12 Nye J.S. Bound to Lead. The Changing Nature of American Power. N.Y, 1990. 
цию «мягкой силы» в новой книге - «Мягкая сила: способы добиться успеха в мировой политике» ${ }^{13}$. Согласно профессору, «мягкую силу» следует понимать как способность государства оказывать влияние на другие страны и общества, на их интересы и поведение в международном политическом и экономическом пространстве. Эта способность должна, в частности, опираться на либеральный режим, развитость, универсальность культуры и мощные средства ее распространения, научно-техническое превосходство, прогрессивную систему образования, передовую коммуникационную систему, национальную и социальную монолитность общества, а также на политическую волю и умение пользоваться этим могуществом и, как результат способность утверждать и отстаивать свою национальную самобытность и свои законные интересы.

История убедительно доказала, что традиционно внешнее могущество утверждалось двумя способами: силовым принуждением или подкупом - т.н. «морковкой». В наше время наиболее рациональным, эффективным и менее затратным признан именно третий, «мягкий» способ: очаровать, «соблазнить», привлечь противника/оппонента на свою сторону. Основным инструментом достижения этой цели сегодня признается «мягкое» поведение державы через продвижение своей культуры (если она привлекательна для других), духовных ценностей (если нет лицемерия в их применении), а также через свои внешнеполитические действия (если они являются легитимными), включая культурную дипломатию.

Степень притягательности той или иной державы, ее международная репутация в данном случае измеряются и подтверждаются числом надежных союзников и партнеров, соответствующими заявлениями представителей элиты других стран, опросами общественного мнения и различными научными исследованиями. По мнению Ная, «мягкое могущество» выше силового или основанного на подкупе, т.к. привлекательность державы ведет к добровольному, а не вынужденному согласию с ней и, следовательно, к сознательному присоединению к её политике и к активному сотрудничеству ${ }^{14}$. Иными словами, «мягкое могущество» означает не военное и даже не экономическое превосходство, а впечатление, которое данная страна производит в мире благодаря привлекательности

13 Nye J.S. Soft Power: The Means to Success in World Politics. N.Y.: Public Affairs, 2004.

14 Ibid. своей культуры и стиля жизни, своим моральным ценностям, обычаям и верованиям, месту в индустрии развлечений, а также всем другим качествам, присущим или приписываемым ее народу.

У Франции присутствует полный набор этих качеств, каждый из которых достоин стать предметом научного анализа. Однако сосредоточим внимание на таком особо важном инструменте «мягкого могущества» Франции, как культурная дипломатия.

\section{Внешняя культурная политика как инструмент «мягкого могущества»}

Важную роль культурного измерения могущества, связанного не только с уровнем научно-технического потенциала, но и с моральными ресурсами страны, в особенности с ее представлением о себе самой, признают и доказывают многие французские ученые ${ }^{15}$. В частности, президент французской Академии моральных и политических наук, видный политолог Тьерри де Монбриаль культуру и идеологию рассматривает в качестве моральных ресурсов, определяющих не только внутреннее единство, но и внешнее влияние страны ${ }^{16}$. Так, Франция стремится закрепить за собой образ «родины прав человека» или носителя «концепции помощи в развитии стран третьего мира» ${ }^{17}$.

Необходимо отметить, что великая французская культура, являясь весомой составной частью уникальной европейской цивилизации, всегда была и остается важнейшим компонентом ее внутренней и внешней политики. И в этом смысле России есть с кого брать пример. Будучи мощным воплощением независимости мышления и яркой самобытности французов как нации, именно культура определила то гордое упорство, с которым Франция, на всем протяжении существования Пятой Республики, противостояла американской культурной гегемонии, стремящейся подчинить законам рынка, оттеснить или нивелировать оригинальные формы самовыражения других великих культурных держав, в том числе и России. В этой связи следует особо подчеркнуть, что, будучи эманацией развитого во всех отношениях демократического общества, родины идеологии и реального

15 Косенко С.В. Культура в палитре внешней политики. Опыт Франции. М: Восток-Запад, 2010. 320 c.

16 Thierry de M. Action et système du monde. Paris: PUF, 2008.

17 Thierry de M. Action et système du monde... P. 65. 
осуществления прав человека, культурное достояние Франции, наряду с его общепризнанными высокими художественными и эстетическими достоинствами, проникнуто духом подлинного демократизма, гуманизма, уважения прав и свобод личности, не в ущерб ярко выраженным национальным чертам. И в этом его особая ценность. Оставаясь и сегодня лидером в области культуры в Европе, Франция, в частности, является единственной развитой страной, где принят закон о защите национального языка. Особый характер носят и протекционистские меры, которые она распространила на аудиовизуальную и ряд других сфер культуры, что может служить примером для других стран, в том числе, и России.

Не будет преувеличением утверждение, что Франция по праву может считаться родоначальницей или «изобретателем» культурной политики. Французские монархи с незапамятных времен окружали себя просвещенными людьми и артистами. «Пионером» покровительства искусств и литературы в этой стране условно можно назвать короля Франсуа (Франциска) I, который, воспротивившись засилью латинского языка, учредил в 1530 г. Королевскую коллегию лекторов, ставшую впоследствии важным институтом французской культуры, известным под именем Коллеж де Франс. В 1539 г. ордонанс короля окончательно закрепил использование французского языка вместо латинского в официальных документах. Более четкая идея политической ответственности публичных властей в области искусства и творчества утвердилась в XVII в., а ее первым реальным институциональным выражением стало создание кардиналом Ришелье в 1635 г. Французской академии. Создание Академии явилось серьезным поворотом в развитии связей между государством и интеллектуально- художественной элитой общества, а также в мощной поддержке со стороны государства развития литературного французского языка.

Иными словами, культурная политика Франции возникла вследствие основанного на сакрально-канонически понимаемых ее правителями национальных идеалах, устойчивого стремления монархических и республиканских властей этой страны брать под свою защиту и покровительство плоды духовной деятельности, искусство и художественное творчество, справедливо считая их высшим национальным достоянием. Постепенно из этой «прихоти» властителей выкристаллизовалась идея политической, затем юридической и, наконец, материальной и административной от- ветственности французского государства в отношении искусств и творчества вообще.

Окончательную институциональную форму культурная политика приобрела в период правления президента Шарля де Голля с созданием в 1959 г. министерства по делам культуры. С этого момента и до начала нового тысячелетия на посту министра культуры сменили друг друга два десятка видных и высокопросвещенных государственных деятелей, пользовавшихся высоким авторитетом в мире культуры и искусства своей страны. Весомый вклад в развитие концепции и институтов французской культурной политики внесли, в частности, такие министры как Андре Мальро и Жак Дюамель. Однако наиболее эффективной и поэтому показательной представляется модель культурной политики, успешно проявившей себя во Франции при президенте-социалисте Франсуа Миттеране (19811995), когда, благодаря целенаправленным усилиям неординарного министра культуры Жака Ланга, культура превратилась не только в динамичную и рентабельную отрасль экономики, но и в прочный бастион защиты национального самосознания и фактор национальной сплоченности французов перед лицом мощного политического, идеологического и лингвокультурного давления Америки.

До последнего времени такая традиционная культурная политика Франции приносила вполне ощутимые плоды. С ее ослаблением связано, в частности, появление во Франции книги историка Антуана де Бэка «Кризисы во французской культуре. Анатомия провала» ${ }^{18}$, в которой автор критически оценивает культурную политику президента Николя Саркози (2007-2012). Нельзя не согласиться с мнением ученого в том, что подход этого президента к вопросам культурной политики больше напоминал американскую модель: сокращение или экономия государственных расходов на эти цели, крен в сторону частного спонсирования, ориентация на количественные показатели и рентабельность, как критерии качества, успеха, что и трактуется им как отход от традиционной французской политики.

Соотношение «могущества» и «влияния» во внешней политике Франции последних лет детально исследовано в работах другого французского ученого, профессора Парижского института политичекских наук Мориса Вайса ${ }^{19}$. В частности,

\footnotetext{
18 Baecque de A. Crises dans la culture française. Anatomie d'un échec. Paris : Bayard, 2008.

19 Vaisse M. La puissance ou 1 influence. La France dans le monde depuis 1958. Paris: Fayard, 2009.
} 
Вайс отмечает, что сакрализация «наследия» и «преемственности» ведет во внутреннем плане к гипертрофии роли президента во Франции и соответственно к маргинализации парламента, а во внешнем плане - к расхождению между словами и делами. В условиях окончания биполярности мира, умножения региональных конфликтов, продвижения европейской интеграции, усиления глобальных вызовов, информационной революции и т.п. Вайс ориентирует руководство своей страны на выработку политики влияния, стыкующейся с реалиями настоящего и устремленной в будущее.

Особое внимание ученый уделяет культурной дипломатии Франции, как инструменту влияния в контексте глобального управления и привлекательной способности. Вайс утверждает, что понятия «влияние» и «мягкое могущество» конвергентны и охватывают сегодня не только и не просто культурное пространство, но и место страны в глобальной системе средств массовой информации, позиции французских транснациональных компаний, достижения в области новых технологий и т.п., позволяя Франции «играть менее или более значительную роль в мировом масштабе» ${ }^{20}$.

Как отмечалось выше, с приходом к власти президента Саркози в 2007 г. во внешней и, соответственно, в культурной политике Франции усилился проамериканский крен. В силу этого политико-экономического выбора или объективных трудностей, начиная примерно с 2009 г., ассигнования на традиционно активную внешнюю культурную деятельность Франции стали ощутимо снижаться. Размеры сокращения этих ассигнований послужили основанием для заявлений, например, в парламенте, об угрозе самой сути внешней культурной деятельности страны. Здравомыслящая часть французской элиты все более настойчиво выражала свою обеспокоенность снижением глобального влияния Франции. В частности, реакцией на сокращение государственных ассигнований культурную деятельность за рубежом стало совместное выступление в газете «Монд» (7 июля 2010 г.) двух бывших министров иностранных дел голлиста Алена Жюппэ и социалиста Юбера Ведрина со статьей «Хватит ослаблять Кэ д’Орсэ». Почти одновременно (15 июля 2010 г.) в журнале «Новый экономист» появилась статья Эмманюэля Лемьё под названием «Проиграла ли Франция войну средствами мягкого могущества?». Этой же теме посвятил целую монографию, вышедшую в 2011 г.,

$20 \quad$ Vaisse M. La puissance ou 1 influence... P. 425. известный политолог Филипп Лан ${ }^{21}$.

Все это, в конечном счете, побудило руководство страны серьезно задуматься о путях если не наращивания, то хотя бы сохранения веса и влияния Франции, как одной из ведущих фигур мировой политики. Так, в директивном письме от 27 августа 2007 г. президент Республики и премьер-министр поручили министру иностранных и европейских дел подготовить т.н. «Белую книгу» для определения приоритетных направлений работы дипломатического аппарата, изменений, которые следует внести в организацию и структуру МИДа и последствий этих изменений для кадровой политики, профессиональной подготовки и развития карьеры дипломатов. Среди пяти приоритетов, обозначенных в письме, наряду с обеспечением безопасности и защитой интересов Франции была сформулирована задача обеспечить более широкое присутствие французских идей, языка и культуры в мире и на службе культурного многобразия. В письме президента подчеркивалось, что руководство страны придаёт «самое большое значение расширению культурного влияния Франции за рубежом, от чего зависит её роль в мире, будущее культурной индустрии и культурное многообразие» ${ }^{22}$.

«Белая книга» по вопросам внешней и европейской политики Франции, подготовленная Комиссией под руководством бывшего министра иностранных дел и премьер-министра Алена Жюппэ и председателя независимого административного органа по борьбе с дискриминацией и за равноправие Луи Швейцером, была вручена президенту Республики ровно через год - 27 августа 2008 года - накануне традиционного совещания послов в Париже. Среди 12 рекомендаций, фигурировавших в книге, содержалось и предложение о пересмотре концепции и проведении радикальной реформы аппарата внешней культурной деятельности страны, как существенного компонента «дипломатии влияния». До этого различные соображения и рекомендации по реорганизации и активизации внешней культурной деятельности страны неоднократно звучали в парламенте ${ }^{23}$.

\footnotetext{
21 Lane Ph. Présence française dan le monde. Laction culturelle et scientifique // La Documentation française, Paris, 2011.

22 https://pastel.diplomatie.gouv.fr/editorial/actual/ael2.

23 Rapport d'information sur les centres culturels français à l'étranger par Yves Dauge au nom de la Commission des affaires étrangères de l'Assemblée nationale. Paris, février 2001 ; Rapport d'information sur la nouvelle stratégie de l'action extérieure de la France par Louis Duvernois au nom de la Commission
} 
Следует напомнить, что с момента появления в 2007 г. претенциозной, если не провокационной, статьи в журнале «Тайм» под заголовком «Смерть французской культуры» во французском обществе и в прессе не прекращалась дискуссия на эту тему. В своем анализе ситуации парламентарии также отталкивались от этой статьи, признавая, что 100 лет спустя после создания первого подразделения во французском МИДе по международным культурным связям - Бюро по делам творчества внешняя культурная деятельность Франции впервые всерьез столкнулась с вызовами, связанными с глобализацией и сокращением бюджетных ассигнований.

В процессе разработки реформы внешней культурной политики Франции развернутые предложения по этому вопросу, с учетом предложений министра иностранных дел Бернара Кушнера, были изложены в докладе № 458, представленном 10 июня 2009 г. сенаторами Жаком Лежандром и Жосленом де Роаном от имени двух сенатских Комиссий - по делам культуры и по иностранным делам и обороне ${ }^{24}$. В известной степени, выводы и рекомендации сенаторов перекликались также с рекомендациями, содержавшимися в экспертном заключении, представленном практически одновременно в другом важном государственном органе Франции - Совете по экономическим, социальным и экологическим вопросам ${ }^{25}$.

Сенаторы, в частности, прямо заявили о кризисе «культурной дипломатии» страны и подвергли критике традиционное и практически эксклюзивное закрепление прерогатив в области внешней культурной политики за министерством иностранных дел. Образно назвав распределение функций в этой области между МИДом и Минкультуры «административной Ялтой», они призвали пересмотреть эту практику, ссылаясь на то, что президентским декретом от 25 мая 2007 г. министерству культуры и коммуникации отводилась более существенная

des affaires culturelles du Sénat. Paris, décembre 2004; Rapport d'information sur la crise de la diplomatie culturelle française par Adrien Gouteyron au nom de la Commission des finances du Sénat. Paris, juillet 2008.

24 Rapport d'information sur le rayonnement culturel international: une ambition pour la diplomatie française par Jacques Legendre et Josselin de Rohan au nom de la Commission des affaires culturelles et de la Commission des affaires étrangères du Sénat, Paris, juin 2009. URL: www.senat.fr/rap/r08-458

25 Le message culturel de la France et la vocation interculturel de la francophonie, Avis présenté par Julia Kristeva-Joyaux au Conseil économique, social et écologique. Paris, juin 2009. роль в обеспечении международного культурного присутствия Франции, артистических обменов и франкофонии. Эта миссия была затем подтверждена в письме от 1 августа 2007 г., адресованном президентом Саркози министру культуры и коммуникации. При этом необходимость усиления роли министерства культуры и коммуникации в сфере внешней культурной политики президент мотивировал не только усилением «европеизации и глобализации ставок в области культурной политики и экономики культуры, но и особой ответственностью данного министерства в аудиовизуальной области» ${ }^{26}$.

\section{Агенты внешней культурной политики Франции}

Декретом от 25 мая 2007 г. за министерством культуры и коммуникации действительно впервые закреплялась важная роль в области международного распространения французской культуры, артистических обменов и франкофонии. В результате Минкультуры стали чаще привлекать, в частности, к международным переговорам по вопросам авторских прав и борьбы с пиратством, обеспечения культурного многообразия, циркуляции коллекций, сотрудничества в борьбе против хищений и незаконного оборота предметов искусства. Более заметную роль, чем прежде, стали играть такие экспортные организации как ТВ Франс Энтернасьональ (TVFI-продажа телепрограмм), ЮниФранс (экспорт отечественных кинофильмов), Бюро по экспорту музыки, Агентство по экспорту архитектуры и Международного бюро по изданию французской литературы, а также службы внешних связей Лувра и музея примитивного искусства на набережной Бранли, находящихся в системе министерства культуры и коммуникации.

В итоге, на основе предложений министра иностранных и европейских дел, а также сводного доклада Сената, 27 июля 2010 г. был принят новый закон о внешней политике государства. Его непосредственным и основным следствием стало учреждение декретом от 30 декабря 2010 г. нового органа под эгидой Кэ д’Орсэ под названием Французский институт (Institut français - не путать c Institut de France, объединяющим французские академии). Однако, тогдашнему амбициозному министру иностранных дел Кушнеру, который инициировал эту реформу, не суждено было заняться ее

26 http://www.artpointfrance.info/article-12277536.html. 
осуществлением - в августе 2010 г. он был вынужден уйти в отставку из-за обострившихся разногласий с советниками Елисейского дворца по внешней политике. На этом посту его сменила видная деятельница голлистской партии Мишель Аллио-Мари, но и ее вскоре отправили в отставку после ошибок, допущенных в отношениях с Тунисом во время т.н. «арабской весны». 1 марта 2011 г. министром иностранных и европейских дел был назначен политический тяжеловес - бывший министр иностранных дел и премьер министр, видный голлист Ален Жюппэ, который в свою бытность министром иностранных дел (1993-1995) при президенте Шираке уделял самое пристальное внимание культурной дипломатии Франции.

Перед Французским институтом была прямо поставлена задача сделать более последовательной, продуманной и планомерной национальную культурную политику за рубежом. Для этого при нем был образован Совет по стратегическим направлениям, которому поручено теснее приобщить к внешней культурной политике министерство культуры и другие заинтересованные ведомства страны. Авторы реформы исходили из того, что по сравнению с иностранными (британскими, немецкими и испанскими) конкурентами французская система внешней культурной политики недостаточно монолитна и эффективна, особенно, с учетом постоянного сокращения бюджетных ассигнований. Если, например, бюджет Института Гёте за последние пять лет увеличился на $30 \%$, а бюджет португальского Института Камоеш вырос в 2010 г. до 40 млн евро, то финансирование французской системы с 2007 по 2009 годы сократилось на $20 \%$. И это на фоне активного расширения в мире глобальных сетей культурного влияния таких стран как Китай (300 отделений в 80 странах с момента создания Института Конфуция в 2004 г.), Бразилия, Индия, Япония, Южная Корея, Тайвань, Абу-Даби, Катар и даже Польша (Институт Адама Мицкевича), которые с некоторых пор стали выделять значительные средства на цели своей «культурной дипломатии». Изначально планировалось, что новое учреждение будет носить имя Виктора Гюго по типу Института Гёте в Германии или Института Сервантеса в Испании. Сенаторы долго дискутировали по этому вопросу. В итоге было принято решение не связывать название Института с чьим-либо именем.

В юридическом смысле статус Французского института определен как государственное учреждение промышленного и коммерческого харак- тера (EPIC), что развязывает ему руки для самостоятельной коммерческой и производственной деятельности, приносящей прибыль. Президентом Французского института был назначен видный дипломат и государственный деятель Франции, сенатор Ксавье Даркос - бывший министр по вопросам труда, социальных отношений и семьи, министр национального образования, министр-делегат по вопросам развития, сотрудничества и франкофонии, а с июня 2010 г. - уполномоченный Совета министров по вопросам внешней культурной политики Франции. В октябре того же года он был избран еще и постоянным секретарем Академии общественных и политических наук. Новый Французский институт унаследовал от своего предшественника (агентства КюльтюрФранс) всю сеть национальных культурных учреждений за рубежом (около 150 культурных служб в посольствах, более 150 культурных центров и свыше 1000 отделений Альянс франсэз). Было решено, что процесс интеграции этих учреждений в новую систему будет развиваться постепенно и выборочно, в экспериментальном порядке, сначала в таких странах как Дания, Великобритания, Индия, ОАЭ, Кувейт, Сирия, Гана, Сенегал, Камбоджа, Сингапур, Чили, Сербия, Грузия и завершится только в 2014 году.

Создавая Французский институт нового типа, правительство преследовало цель укрепить аппарат «дипломатии влияния», сосредоточив в «одних руках» разбросанные ранее между различными учреждениями функции внешней культурной политики страны. Французский институт, в партнерстве с министерством культуры и коммуникации, отныне тоже занимается приемом и распространением во Франции зарубежной культуры в форме «сезонов», фестивалей и т.П., а также координирунт профессиональную подготовку специалистов по вопросам культуры и искусства для работы за рубежом.

В тесном взаимодейстии с системой Французского института должны работать также некоторые другие устоявшиеся французские автономные учреждения, действующие на поприще распространения национальной культуры, как, например, Агентство по преподаванию французского языка за рубежом (AEFE), Агентство по распространению технической информации (ADIT), холдинг «Внешнее аудиовизуальное агентство Франции» и др. В деле распространения французского языка Французский институт, на основе специального соглашения, намерен вплотную сотрудничать с Альянс франсэз, чьи отделения за рубежом также сохранят свою автономию. 
Предполагается тесное взаимодействие Французского института и с другими структурами, созданнами в развитие закона от 27 июля 2010 г., как, например, Campus France (привлечение зарубежных студентов на учебу во французские вузы) и Egide (прием и размещение иностранных стипендиатов). Кроме того, в новой системе особое место займёт государственное учреждение под названием Международная экспертиза Франции (France expertise internationale), которому поручено заниматься пропагандой достижений французской науки, продвижением т.н. «научной культуры» и сотрудничеством в этой области.

В начале февраля 2011 г. на совместном заседании сенатских Комиссий по иностранным делам и по делам культуры были проведены слушания нового президента Французского института Ксавье Даркоса о его планах работы во главе нового учреждения. В начале дискуссии, председатель Комиссии по культуре Жак Лежандр (один из авторов реформы) напомнил, что Франция была «изобретателем» культурной дипломатии и должна думать о повышении динамизма интеллектуального, культурного и лингвистического сотрудничества с другими странами, а также об укреплении сети своих культурных учреждений за рубежом. Пора отказаться от элитарного подхода к распространению французского языка, подчеркнул он, и, по примеру других стран, больше опираться на современные технологии. В этом смысле Франция отстает даже от Испании.

В своем выступлении Даркос сообщил, что первый принцип принятого закона был успешно воплощен в жизнь - все зарубежные культурные учреждения Франции объединены под одной крышей и этот процесс должен быть завершен в течение 2012 года. Под эгидой министерства иностранных и европейских дел Французский институт стал единым оператором внешней культурной сети и, действуя в контакте со всеми заинтересованными министерствами и ведомствами страны, готов обеспечить «культурную поддержку» дипломатической стратегии Франции. Выполнено и другое требование закона - все французские культурные учреждения за рубежом будут носить единое название - Французский институт. Численность сотрудников Института может достигнуть 200 человек, в т.ч. почти половина бывших сотрудников аппарата КюльтюрФранс, 40 чел перейдут из МИДа, около десяти из министерства культуры и из министерства национального образования.

Также Даркос с тревогой отметил, что в области приложения «soft power» или «дипломатии влияния» Франция сталкивается с жесткой конкуренцией, т.к. почти все каналы распространения культуры в мире находятся в руках американцев. По его словам, можно даже сказать, что в условиях глобализации происходит американизация знаний. Мощную глобальную сеть влияния развернул Китай - институтов Конфуция сегодня в мире больше чем Французских институтов. Поэтому свою первоочередную задачу Институт его руководство видит в том, чтобы сделать Францию более конкурентоспособной в этой сфере. В этой связи один из сенаторов, участвовавших в дискуссии, призвал оратора шире использовать мощный потенциал национальной кино- и музыкальной индустрии в сотрудничестве со странами, желающими «защищать культурное разнообразие от униформирующего воздействия Соединенных Штатов» ${ }^{27}$.

\section{Есть ли будущее у неамериканской культурной политики?}

Ослабление французского культурного влияния в мире не может не беспокоить искренних друзей Франции и поклонников ее культуры. Как не может не волновать тот факт, что сегодня весь культурный мир планеты, включая Россию, живет, в сущности, по американским стандартам, следуя за рейтингом американских блокбастеров, бестселлеров, музыкальных хитов и клипов, все чаще под Новый год по России звучит «Джингл беллз» вместо родной «Елочки». К сожалению, все сто каналов русскоязычного цифрового телевидения забиты голливудскими сериалами и триллерами. И хотя их постепенно вытесняют отечественные сериалы, но слеплены они оказываются абсолютно по таким же неприхотливым американским шаблонам - побольше насилия или суспенса, в меру секса и нужная доза слащавой сентиментальности. Выстоять в этом океане дешевки и непритязательности можно только с опорой на настоящую, высокую культуру. В этом смысле опыт Франции, которая всегда оставалась проводником Искусства, а не ширпотреба, заслуживает пристального изучения.

Но даже если сегодня «высокая» французская культура, действительно, сдает свои позиции, и ее влияние в мире ослабевает, то слухи о её смерти все же сильно преувеличены. Все факторы общепризнанного культурного превосходства Франции пока еще в силе: богатейшее историческое наследие, великая литература и философия, передовые

27 www.senat.fr/compte-rendu-commissions/20110.htm. 
высшие школы и современные технологии, непревзойденные музыка, живопись и архитектура, неповторимые высокая мода, парфюмерия и индустрия роскоши, высокая гастрономия, виноделие и т.д. Но самое главное - это жизнеутверждающий, разумный и здоровый образ жизни и мышления, разительно отличающийся от якобы «свободного», а на самом деле уродливого и лицемерного американского менталитета, зацикленного на изнурительной и бессмысленной погоне за «успехом», читай деньгами. Ясно одно - могучий потенциал французского культурного влияния в мире далеко не исчерпан, а потому российским политикам и дипломатам следует не только внимательно и бережно изучать яркие страницы истории культурной дипломатии Франции, но тесно сотрудничать с французскими коллегами. Лишь совместными усилиями мы сможем сохранить национальную самобытность и обеспечить миру выбор - альтернативу американской культурной гегемонии.

\section{Библиография:}

1. Выступление Президента РФ на Совещании послов и постоянных представителей России. 9 июля 2012. URL: http://президент.pф/news/15902.

2. Пономарева Е.Г. Железная хватка «мягкой силы» // Однако. 2013. № 6. URL: http://www.odnako.org/magazine/ material/show_24128.

3. Braudel F. Grammaire des civilisations. Paris: Arthaud, 1987. P. 13-14.

4. Adorno T., Horkheimer M. Dialectic of Enlightenment. Stanford: Stanford UP, 2002. 304 p.

5. Montbrial de Th. Vingt ans qui boulversèrent le monde. Paris: Dunod, 2008;.

6. Vaïsse M. La puissance ou l'influence? La France dans le monde depuis 1958. Paris: Fayard, 2009.

7. Алексеева Т.А. Россия в пространстве глобального восприятия // Международные процессы. 2007. Том 5. №2 (14);

8. Обичкина Е.О. Франция в поисках внешнеполитических ориентиров в постбиполярном мире. М.: МГИМо-Университет, 2003;

9. Филимонов Г.Ю. «Мягкая сила» культурной дипломатии США. М.: РУДН, 2010.

10. Нарочницкая Н.А. Россия и русские в современном мире. М.: ЭКСМО, 2011. С. 263.

11. Aron, R. Paix et guerre entre les nations. Paris: Calmann-Lévy, 1984. P. 58.

12. Nye J.S. Bound to Lead. The Changing Nature of American Power. N.Y, 1990.

13. Nye J.S. Soft Power: The Means to Success in World Politics. N.Y.: Public Affairs, 2004.

14. Косенко С.В. Культура в палитре внешней политики. Опыт Франции. М: Восток-Запад, 2010. 320 с.

15. Thierry de M. Action et système du monde. Paris: PUF, 2008.

16. Baecque de A. Crises dans la culture française. Anatomie d'un échec. Paris : Bayard, 2008.

17. Vaisse M. La puissance ou l influence. La France dans le monde depuis 1958. Paris: Fayard, 2009.

18. Lane Ph. Présence française dan le monde. L'action culturelle et scientifique // La Documentation française, Paris, 2011. 19. https://pastel.diplomatie.gouv.fr/editorial/actual/ael2.

20. Rapport d'information sur les centres culturels français à l'étranger par Yves Dauge au nom de la Commission des affaires étrangères de l'Assemblée nationale. Paris, février 2001;

21. Rapport d'information sur la nouvelle stratégie de l [action extérieure de la France par Louis Duvernois au nom de la Commission des affaires culturelles du Sénat. Paris, décembre 2004;]

22. Rapport d'information sur la crise de la diplomatie culturelle française par Adrien Gouteyron au nom de la Commission des finances du Sénat. Paris, juillet 2008.

23. Rapport d'information sur le rayonnement culturel international: une ambition pour la diplomatie française par Jacques Legendre et Josselin de Rohan au nom de la Commission des affaires culturelles et de la Commission des affaires étrangères du Sénat, Paris, juin 2009. URL: www.senat.fr/rap/r08-458

24. Le message culturel de la France et la vocation interculturel de la francophonie, Avis présenté par Julia Kristeva-Joyaux au Conseil économique, social et écologique. Paris, juin 2009.

25. http://www.artpointfrance.info/article-12277536.html.

26. www.senat.fr/compte-rendu-commissions/20110.htm.

\section{References (transliterated):}

1. Vystuplenie Prezidenta RF na Soveshchanii poslov i postoyannykh predstavitelei Rossii. 9 iyulya 2012. URL: http:// prezident.rf/news/15902.

2. Ponomareva E.G. Zheleznaya khvatka «myagkoi sily» // Odnako. 2013. № 6. URL: http://www.odnako.org/magazine/ material/show_24128.

3. Braudel F. Grammaire des civilisations. Paris: Arthaud, 1987. R. 13-14.

4. Adorno T., Horkheimer M. Dialectic of Enlightenment. Stanford: Stanford UP, 2002. 304 r.

5. Montbrial de Th. Vingt ans qui boulversèrent le monde. Paris: Dunod, 2008;.

6. Vaïsse M. La puissance ou l'influence? La France dans le monde depuis 1958. Paris: Fayard, 2009.

7. Alekseeva T.A. Rossiya v prostranstve global'nogo vospriyatiya // Mezhdunarodnye protsessy. 2007. Tom 5. №2 (14); 


\section{Международные отношения / International Relations / № 2 / 2015}

8. Obichkina E.O. Frantsiya v poiskakh vneshnepoliticheskikh orientirov v postbipolyarnom mire. M.: MGIMO-Universitet, 2003;

9. Filimonov G.Yu. «Myagkaya sila» kul'turnoi diplomatii SShA. M.: RUDN, 2010.

10. Narochnitskaya N.A. Rossiya i russkie v sovremennom mire. M.: EKSMO, 2011. S. 263.

11. Aron, R. Paix et guerre entre les nations. Paris: Calmann-Lévy, 1984. P. 58.

12. Nye J.S. Bound to Lead. The Changing Nature of American Power. N.Y, 1990.

13. Nye J.S. Soft Power: The Means to Success in World Politics. N.Y.: Public Affairs, 2004.

14. Kosenko C.B. Kul'tura v palitre vneshnei politiki. Opyt Frantsii. M: Vostok-Zapad, 2010. 320 c.

15. Thierry de M. Action et système du monde. Paris: PUF, 2008.

16. Baecque de A. Crises dans la culture française. Anatomie d'un échec. Paris : Bayard, 2008.

17. Vaisse M. La puissance ou 1 influence. La France dans le monde depuis 1958. Paris: Fayard, 2009.

18. Lane Ph. Présence française dan le monde. L'action culturelle et scientifique // La Documentation française, Paris, 2011.

19. https://pastel.diplomatie.gouv.fr/editorial/actual/ael2.

20. Rapport d'information sur les centres culturels français à l'étranger par Yves Dauge au nom de la Commission des affaires étrangères de l'Assemblée nationale. Paris, février 2001;

21. Rapport d'information sur la nouvelle stratégie de l [action extérieure de la France par Louis Duvernois au nom de la Commission des affaires culturelles du Sénat. Paris, décembre 2004;]

22. Rapport d'information sur la crise de la diplomatie culturelle française par Adrien Gouteyron au nom de la Commission des finances du Sénat. Paris, juillet 2008.

23. Rapport d'information sur le rayonnement culturel international: une ambition pour la diplomatie française par Jacques Legendre et Josselin de Rohan au nom de la Commission des affaires culturelles et de la Commission des affaires étrangères du Sénat, Paris, juin 2009. URL: www.senat.fr/rap/r08-458

24. Le message culturel de la France et la vocation interculturel de la francophonie, Avis présenté par Julia Kristeva-Joyaux au Conseil économique, social et écologique. Paris, juin 2009.

25. http://www.artpointfrance.info/article-12277536.html.

26. www.senat.fr/compte-rendu-commissions/20110.htm. 